\title{
Cross-sectional study of malocclusion in Spanish children
}

\author{
José-Manuel Almerich-Silla ${ }^{1}$, José-María Montiel-Company ${ }^{2}$, Carlos Bellot-Arcís ${ }^{3}$, Neus Puertes-Fernández ${ }^{4}$ \\ ${ }^{1}$ Tenured Lecturer, Stomatology Department, Faculty of Medicine and Dentistry, University of Valencia (Spain) \\ ${ }^{2}$ Post-Doctoral Assistant Professor, Stomatology Department, Faculty of Medicine and Dentistry, University of Valencia \\ (Spain) \\ ${ }^{3}$ Adjunct Professor, Stomatology Department, Faculty of Medicine and Dentistry, University of Valencia (Spain) \\ ${ }^{4} \mathrm{PhD}$ student, Stomatology, Department, Faculty of Medicine and Dentistry, University of Valencia (Spain)
}

Correspondence:

Departamento de Estomatología,

Unidad de Odontología Preventiva y Comunitaria

Clínica Odontológica

C/ Gascó Oliag $n^{\circ} 1$,

46010, Valencia, Spain

jose.m.almerich@uv.es

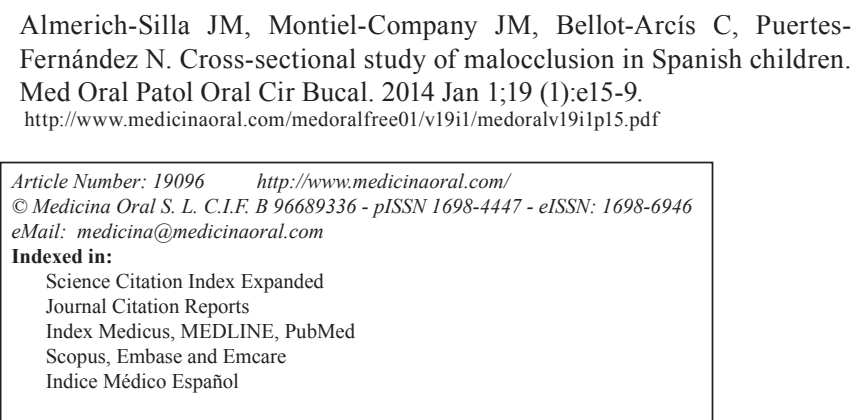

\begin{abstract}
Objectives: This study was conducted to determine the orthodontic treatment need of the child population of the Valencia region of Spain, employing the DAI and the IOTN, to examine the relations between treatment need, socio-economic data and gender and to assess the diagnostic agreement between the two indices.

Study Design: A cross-sectional descriptive study was conducted in a random representative sample of the schoolchild population of the Valencia region of Spain. The sample size was a total of 765 children aged 12 and 15 years at 39 schools.

Results: The orthodontic treatment need assessed by the DAI was $21.7 \%$ at 12 years of age and $14.1 \%$ at 15 years. The orthodontic treatment need assessed by the IOTN DHC was $20.9 \%$ at 12 years of age and $12.7 \%$ at 15 years. The diagnostic agreement between the DAI and the modified IOTN was moderate, with Kappa scores of 0.426 at 12 years of age and 0.415 for the 15 -year-old group.

Conclusions: Approximately $20 \%$ of the children needed orthodontic treatment. Neither gender nor social class appeared to exert a significant influence on orthodontic treatment need.
\end{abstract}

Key words: Orthodontics, epidemiology, children, malocclusion.

\section{Introduction}

Many occlusal or orthodontic treatment need indices are described in the literature, although there is no consensus on which it is best to use (1). Of them all, the Dental Aesthetic Index (DAI) and the Index of Orthodontic Treatment Need (IOTN) have demonstrated their validity in epidemiological studies; the DAI is even used for the WHO's epidemiological surveys, increasing its use and acceptance among the scientific community.

The IOTN classifies malocclusions according to the occlusal components considered important for health and dental aesthetics. Its aim is to identify which individuals would most benefit from orthodontic treatment. The IOTN comprises a Aesthetic Component (AC) with 10 
severity levels and a Dental Health Component (DHC) with five severity levels. The two are analysed separately and although they cannot be united into a single score, they can be combined to classify the patient's orthodontic treatment need as Yes or No. This result is known as modified IOTN.

The distinctive feature of the DAI is that this orthodontic index relates the clinical and aesthetic components mathematically to give a single score. This can be classed into 4 grades of orthodontic treatment need.Both of these indices have been used in previous epidemiological studies to assess orthodontic treatment need in Spain $(2,3)$.

This study was conducted to determine the orthodontic treatment need of the child population of the Valencia region of Spain, employing the DAI and the IOTN, examine the relations between treatment need, socio-economic data and gender and assess the diagnostic agreement between the two indices.

\section{Material and Methods}

A descriptive cross-sectional study was conducted in a random representative sample of the schoolchild population of the Valencia region of Spain. Cluster sampling was performed to decide the schools in which the examinations would be conducted. All the schools in the Valencia region were included in the sampling process. It was also estimated that the mean number of examinations to be carried out in each of the selected schools should be between 15 and 25 pupils attending a total of 39 schools. The examinations were carried out in a classroom at each school. The examination instruments employed were a WHO-type periodontal probe and a plain mouth mirror. The sample size was 765 children aged 12 and 15 years.

The 3 examiners underwent prior calibration to assess the agreement between their DAI and IOTN orthodontic treatment need diagnoses of study models and those of a reference examiner acting as a 'gold standard' (Kappa $>0.85$ ). A second calibration test was then carried out with 20 pupils, examined under the same conditions as in the survey to be conducted (Kappa $>0.85$ ).

To determine the orthodontic treatment need, the Dental Aesthetic Index (DAI) and both components (DHC and $\mathrm{AC}$ ) of the Index of Orthodontic Treatment Need (IOTN) were employed. The aesthetic component (AC) was assessed by both the child (AC patient) and the examiner (AC examiner).

The classification of social class was based on that of the UK Registrar (4). Social classes I - professional and II - intermediate - were considered high. Social classes III N - skilled non-manual - and III M - skilled manual - were considered middle. Social classes IV partly skilled - and V - unskilled - were considered low. All others were not classified.

The study was approved by the Ethical Committee of the University of Valencia and the Helsinki recommendations for this type of study were followed. Informed consent was obtained from the children's parents to conduct the examinations, which were performed in November and December 2010.

The data were stored in a Microsoft ${ }^{\circledR}$ Access 2007 $®$ database. The statistical analysis was carried out with IBM ${ }^{\circledR}$ SPSS v $19.0 \circledR$ software.

The univariate descriptive statistics obtained were the means and $95 \%$ confidence intervals (CI 95\%) for the quantitative variables and the percentages and 95\% confidence intervals (CI 95\%) for the categorical variables. For bivariate data analysis the chi square test was used for comparison of proportions, with a significance level of $\mathrm{p} \leq 0.05$. The Kappa statistic was employed to determine diagnostic agreement.

\section{Results}

Of the 765 children examined, 397 were 12 years old and 368 were 15 years old. The percentage who had received orthodontic treatment was significantly higher in the 15 year-old age group than among the 12-year-olds: $27.2 \%$ for the former compared to $7.1 \%$ for the latter (chi-square test $\mathrm{p}=0.000$ ).

The orthodontic treatment need determined by the DAI was $21.7 \%$ in grades 3 and 4 at 12 years of age and $14.1 \%$ in grades 3 and 4 at 15 years of age. The mean DAI scores were 26.6 and 24.5 at 12 and 15 years respectively. The 15-year-old group exhibited significantly less treatment need than the 12-year-olds (chi-square test $\mathrm{p}=0.003)$. Table 1 shows the percentage distribution and mean scores in each grade of treatment need according to the DAI for the two age groups.

With the IOTN DHC, the treatment needs obtained were $20.9 \%$ in grades 4 and 5 at 12 years of age and $12.7 \%$ in grades 4 and 5 at 15 years, showing significant differences (chi-square test $\mathrm{p}=0.001$ ). With the IOTN $\mathrm{AC}$ the differences were equally significant (chi-square test $\mathrm{p}=0.000$ ), as the results for grades $8-10$ were $5.5 \%$ for the 12 -year-olds and $1.1 \%$ for the 15 -year-olds as assessed by the children and $7.6 \%$ and $3.3 \%$ respectively as assessed by the examiners (Table 2). The need determined by the modified IOTN (IOTN DHC grades 4-5 or patient-assessed IOTN AC grades $8-10$ ) was $23.7 \%$ $(19.7 \%-28.1 \%)$ at 12 years and $13.3 \%(10.2 \%-17.1 \%)$ at 15 years, a significant difference (chi-square test $\mathrm{p}=0.000$ ).

The diagnostic agreement between the DAI and the modified IOTN was moderate, obtaining Kappa scores of 0.426 for the 12-year-old group and 0.415 for the 15 year-old group.

On comparing the orthodontic treatment need after excluding those who had received orthodontic treatment $(n=637)$, no significant differences were found in either the DAI $(\mathrm{p}=0.07)$ or the IOTN $(\mathrm{p}=0.31)$ results. 
Table 1. Percentage and mean distribution of Dental Aesthetic Index (DAI) treatment need grades at 12 and 15 years of age.

\begin{tabular}{|c|c|c|c|c|c|}
\hline \multirow[b]{2}{*}{$\begin{array}{l}\text { DAI } \\
\text { Grade }\end{array}$} & \multicolumn{2}{|c|}{12 years $(n=397)$} & \multicolumn{2}{|c|}{15 years $(n=368)$} & \multirow[b]{2}{*}{$\begin{array}{l}\text { Chi' }{ }^{2} \text { test } \\
\text { P value }\end{array}$} \\
\hline & $\begin{array}{c}\% \\
(\mathrm{CI}-95 \%)\end{array}$ & $\begin{array}{c}\text { Mean } \\
(\mathrm{CI}-95 \%)\end{array}$ & $\begin{array}{c}\% \\
(\mathrm{CI}-95 \%)\end{array}$ & $\begin{array}{c}\text { Mean } \\
(\mathrm{CI}-95 \%)\end{array}$ & \\
\hline $\begin{array}{l}\text { 1. No treatment need } \\
\leq 25\end{array}$ & $\begin{array}{c}52.1 \\
(47.2-57.0)\end{array}$ & $\begin{array}{c}21.8 \\
(21.4-22.2)\end{array}$ & $\begin{array}{c}63.6 \\
(58.6-68.3)\end{array}$ & $\begin{array}{c}20.8 \\
(20.5-21.3)\end{array}$ & $\mathrm{P}=0.003^{*}$ \\
\hline $\begin{array}{l}\text { 2. Treatment elective } \\
26-30\end{array}$ & $\begin{array}{c}26.2 \\
(22.1-30.7)\end{array}$ & $\begin{array}{c}28.3 \\
(28.1-28.6)\end{array}$ & $\begin{array}{c}22.3 \\
(18.3-16.8)\end{array}$ & $\begin{array}{c}28.2 \\
(28.0-28.6)\end{array}$ & \\
\hline $\begin{array}{l}\text { 3. Treatment desirable } \\
31-35\end{array}$ & $\begin{array}{c}13.1 \\
(10.1-16.8)\end{array}$ & $\begin{array}{c}33.1 \\
(32.7-33.5)\end{array}$ & $\begin{array}{c}10.3 \\
(7.60-13.9)\end{array}$ & $\begin{array}{c}33.0 \\
(32.5-33.5) \\
\end{array}$ & \\
\hline $\begin{array}{l}\text { 4. Treatment mandatory } \\
\geq 36\end{array}$ & $\begin{array}{c}8.6 \\
(6.20-11.7)\end{array}$ & $\begin{array}{c}40.4 \\
(38.7-42.1)\end{array}$ & $\begin{array}{c}3.8 \\
(2.3-6.3)\end{array}$ & $\begin{array}{c}40.5 \\
(37.9-43.1)\end{array}$ & \\
\hline
\end{tabular}

* Significant differences $(\mathrm{p}<0.05)$ in chi-square test. CI-95\%: 95\% confidence Interval.

Table 2. Percentage distribution of Index of Orthodontic Treatment Need (IOTN) grades at 12 and 15 years of age.

\begin{tabular}{|c|c|c|c|c|}
\hline & & $\begin{array}{c}12 \text { years }(n=397) \\
\% \\
(\text { CI-95\%) }\end{array}$ & $\begin{array}{c}15 \text { years }(n=368) \\
\% \\
(C I-95 \%)\end{array}$ & $\begin{array}{c}\text { Chi }^{2} \text { test } \\
\text { P value }\end{array}$ \\
\hline \multirow[t]{5}{*}{ IOTN DHC } & $\begin{array}{l}\text { Grade } 1 . \text { No malocclusion. } \\
\text { No need for treatment }\end{array}$ & $\begin{array}{c}13.9 \\
(10.8-17.6) \\
\end{array}$ & $\begin{array}{c}23.6 \\
(19.6-28.2) \\
\end{array}$ & \multirow[t]{5}{*}{$\mathrm{P}=0.001 *$} \\
\hline & $\begin{array}{l}\text { Grade 2. Minor malocclusion. } \\
\text { Little need for treatment }\end{array}$ & $\begin{array}{c}38.0 \\
(33.4-42.9)\end{array}$ & $\begin{array}{c}38.6 \\
(33.8-43.7)\end{array}$ & \\
\hline & $\begin{array}{l}\text { Grade 3. Moderate malocclusion. } \\
\text { Borderline need for treatment }\end{array}$ & $\begin{array}{c}27.2 \\
(23.1-31.8)\end{array}$ & $\begin{array}{c}25.0 \\
(20.8-29.7)\end{array}$ & \\
\hline & $\begin{array}{l}\text { Grade } 4 \text {. Severe malocclusion. } \\
\text { Needs treatment }\end{array}$ & $\begin{array}{c}17.1 \\
(13.7-21.1)\end{array}$ & $\begin{array}{c}10.3 \\
(7.6-13.9)\end{array}$ & \\
\hline & $\begin{array}{l}\text { Grade } 5 \text {. Very severe malocclusion. } \\
\text { Needs treatment }\end{array}$ & $\begin{array}{c}3.8 \\
(2.30-6.10)\end{array}$ & $\begin{array}{c}2.4 \\
(1.3-4.6)\end{array}$ & \\
\hline \multirow[t]{3}{*}{$\begin{array}{l}\text { IOTN AC } \\
\text { Patient }\end{array}$} & $\begin{array}{l}\text { Grades 1-4 } \\
\text { No need for treatment }\end{array}$ & $\begin{array}{c}85.9 \\
(82.1-88.9) \\
\end{array}$ & $\begin{array}{c}95.7 \\
(93.0-97.3) \\
\end{array}$ & \multirow[t]{3}{*}{$\mathrm{P}=0.000^{*}$} \\
\hline & $\begin{array}{l}\text { Grades 5-7 } \\
\text { Borderline need }\end{array}$ & $\begin{array}{c}8.6 \\
(6.2-11.7)\end{array}$ & $\begin{array}{c}3.3 \\
(1.9-5.6)\end{array}$ & \\
\hline & $\begin{array}{l}\text { Grades } 8-10 \\
\text { Definite need for treatment }\end{array}$ & $\begin{array}{c}5.5 \\
(3.7-8.0)\end{array}$ & $\begin{array}{c}1.1 \\
(0.4-2.8)\end{array}$ & \\
\hline \multirow[t]{3}{*}{$\begin{array}{l}\text { IOTN AC } \\
\text { Examiner }\end{array}$} & $\begin{array}{l}\text { Grades } 1-4 \\
\text { No need for treatment }\end{array}$ & $\begin{array}{c}78.1 \\
(73.7-81.9)\end{array}$ & $\begin{array}{c}89.7 \\
(86.1-92.3)\end{array}$ & \multirow[t]{3}{*}{$\mathrm{P}=0.000^{*}$} \\
\hline & $\begin{array}{l}\text { Grades 5-7 } \\
\text { Borderline need }\end{array}$ & $\begin{array}{c}14.4 \\
(11.2-18.1)\end{array}$ & $\begin{array}{c}7.1 \\
(4.8-10.1)\end{array}$ & \\
\hline & $\begin{array}{l}\text { Grades } 8-10 \\
\text { Definite need for treatment }\end{array}$ & $\begin{array}{c}7.6 \\
(5.3-10.6) \\
\end{array}$ & $\begin{array}{c}3.3 \\
(1.9-5.6) \\
\end{array}$ & \\
\hline
\end{tabular}

* Significant differences $(\mathrm{p}<0.05)$ in chi-square test. CI-95\%: 95\% confidence Interval.

In relation to gender, no significant differences were found with any of the indices employed, whether DAI (chi-square test $\mathrm{p}=0.414$ ), IOTN DHC (chi-square test $\mathrm{p}=0.186$ ), IOTN AC patient (chi-square test $\mathrm{p}=0.095$ ), IOTN AC examiner (chi-square test $\mathrm{p}=0.075$ ) or modified IOTN (chi-square test $\mathrm{p}=0.139$ ).

Table 3 presents the percentage distribution of the different grades of treatment by index and social class. No significant differences were found with the DAI (chi-square test $\mathrm{p}=0.533$ ), IOTN DHC (chi-square test $\mathrm{p}=0.062$ ) or IOTN AC assessed by the children (chisquare test $\mathrm{p}=0.622$ ). However, the IOTN AC assessed by the examiner showed a significantly higher treatment need in the low social class group (chi-square test $\mathrm{p}=0.009$ ).

\section{Discussion}

Many occlusal indices have been developed to classify malocclusions according to their severity or orthodontic treatment need. Although there is a certain consensus about the requirements that occlusal indices must meet, it is very difficult to develop an index that can win the recognition of the international research community, making it difficult for this work to develop and hindering subsequent comparisons with other studies.

Whether this type of study should include or exclude persons who have previously received orthodontic treatment has always been a controversial question. Some authors exclude them $(5,6)$ while others include them (7-9). In order to obtain a representative sample, patients undergoing orthodontic treatment at the time 
Table 3. Percentage distribution of the different grades of treatment by index and social class.

\begin{tabular}{|c|c|c|c|c|c|}
\hline & & $\begin{array}{c}\text { Social class } \\
\text { Low } \mathbf{n}=353 \\
\% \\
(\mathbf{C I}-95 \%) \\
\end{array}$ & $\begin{array}{c}\text { Social class } \\
\text { Middle n=296 } \\
\% \\
(\mathrm{CI}-95 \%) \\
\end{array}$ & $\begin{array}{c}\text { Social class } \\
\text { High n=116 } \\
\% \\
(\mathrm{CI}-95 \%) \\
\end{array}$ & $\begin{array}{c}\text { Chi }^{2} \text { test } \\
\text { P value }\end{array}$ \\
\hline \multirow[t]{2}{*}{ DAI } & $\begin{array}{l}\text { Grades 1-2 } \\
\text { No need }\end{array}$ & $\begin{array}{c}80.7 \\
(76.3-84.5) \\
\end{array}$ & $\begin{array}{c}82.1 \\
(77.3-86.0) \\
\end{array}$ & $\begin{array}{c}85.3 \\
(77.7-90.6) \\
\end{array}$ & \multirow[t]{2}{*}{$\mathrm{P}=0.533$} \\
\hline & $\begin{array}{l}\text { Grades 3-4 } \\
\text { Definite need }\end{array}$ & $\begin{array}{c}19.3 \\
(15.4-23.7)\end{array}$ & $\begin{array}{c}17.9 \\
(13.9-22.7)\end{array}$ & $\begin{array}{c}14.7 \\
(9.4-22.2)\end{array}$ & \\
\hline \multirow[t]{3}{*}{$\begin{array}{l}\text { IOTN } \\
\text { DHC }\end{array}$} & $\begin{array}{l}\text { Grades 1-2 } \\
\text { No need }\end{array}$ & $\begin{array}{c}51.8 \\
(46.6-57.0)\end{array}$ & $\begin{array}{c}59.5 \\
(53.7-64.8)\end{array}$ & $\begin{array}{c}65.5 \\
(56.4-73.5)\end{array}$ & \multirow[t]{3}{*}{$\mathrm{P}=0.062$} \\
\hline & $\begin{array}{l}\text { Grade } 3 . \\
\text { Borderline need }\end{array}$ & $\begin{array}{c}28.3 \\
(23.8-33.2)\end{array}$ & $\begin{array}{c}26.0 \\
(21.3-31.3)\end{array}$ & $\begin{array}{c}19.8 \\
(13.5-27.9)\end{array}$ & \\
\hline & $\begin{array}{l}\text { Grades } 4-5 \\
\text { Definite need }\end{array}$ & $\begin{array}{c}19.8 \\
(16.0-24.3) \\
\end{array}$ & $\begin{array}{c}14.5 \\
(10.9-18.9) \\
\end{array}$ & $\begin{array}{c}14.7 \\
(9.4-22.2) \\
\end{array}$ & \\
\hline \multirow[t]{3}{*}{$\begin{array}{l}\text { IOTN AC } \\
\text { Patient }\end{array}$} & $\begin{array}{l}\text { Grades 1-4 } \\
\text { No need }\end{array}$ & $\begin{array}{c}91.5 \\
(88.1-93.9) \\
\end{array}$ & $\begin{array}{c}89.2 \\
(85.1-92.2) \\
\end{array}$ & $\begin{array}{c}91.4 \\
(84.8-95.3)\end{array}$ & \multirow[t]{3}{*}{$\mathrm{P}=0.622$} \\
\hline & $\begin{array}{l}\text { Grades 5-7 } \\
\text { Borderline need }\end{array}$ & $\begin{array}{c}5.9 \\
(3.9-8.9) \\
\end{array}$ & $\begin{array}{c}6.1 \\
(3.8-9.4) \\
\end{array}$ & $\begin{array}{c}6.0 \\
(2.9-11.9) \\
\end{array}$ & \\
\hline & $\begin{array}{l}\text { Grades } 8-10 \\
\text { Definite need }\end{array}$ & $\begin{array}{c}2.5 \\
(1.3-4.7)\end{array}$ & $\begin{array}{c}4.7 \\
(2.8-7.8)\end{array}$ & $\begin{array}{c}2.6 \\
(0.8-7.3)\end{array}$ & \\
\hline \multirow[t]{3}{*}{$\begin{array}{l}\text { IOTN AC } \\
\text { Examiner }\end{array}$} & $\begin{array}{l}\text { Grades 1-4 } \\
\text { No need }\end{array}$ & $\begin{array}{c}79.1 \\
(75.3-83.7)\end{array}$ & $\begin{array}{c}85.1 \\
(80.6-88.7) \\
\end{array}$ & $\begin{array}{c}91.4 \\
(84.8-95.3) \\
\end{array}$ & \multirow[t]{3}{*}{$\mathrm{P}=0.009^{*}$} \\
\hline & $\begin{array}{l}\text { Grades 5-7 } \\
\text { Borderline need }\end{array}$ & $\begin{array}{c}11.9 \\
(8.9-15.7) \\
\end{array}$ & $\begin{array}{c}11.5 \\
(8.3-15.6) \\
\end{array}$ & $\begin{array}{c}6.0 \\
(2.9-11.9) \\
\end{array}$ & \\
\hline & $\begin{array}{l}\text { Grades } 8-10 \\
\text { Definite need }\end{array}$ & $\begin{array}{c}8.2 \\
(5.7-11.5)\end{array}$ & $\begin{array}{c}3.4 \\
(1.8-6.1)\end{array}$ & $\begin{array}{c}2.6 \\
(0.8-7.3)\end{array}$ & \\
\hline
\end{tabular}

* Significant differences $(\mathrm{p}<0.05)$ in chi-square test. CI-95\%: $95 \%$ confidence Interval.

the examinations took place were excluded from the present study but those who had received such treatment in the past were included.

On examining the orthodontic treatment need by age group, it was observed that the 15 -year-olds had significantly less need of treatment than the 12-year-olds. This result was observed irrespectively of the index employed, whether DAI, IOTN DHC, patient-assessed IOTN AC or examiner-assessed IOTN AC. It is explained by the percentage who had previously received orthodontic treatment, which was significantly higher in the 15-year-old group than in the 12-year-old group. Moreover, the differences in orthodontic treatment need ceased to be statistically significant when those who had received orthodontic treatment in the past were excluded.

The orthodontic treatment need assessed by the DAI was $21.7 \%$ at 12 years of age and $14.1 \%$ at 15 years. Manzanera et al. obtained very similar treatment needs: $21.2 \%$ and $16.1 \%$ for the 12 and 15 -year-old groups respectively (10). Other studies have also encountered very similar figures (11-14).

The orthodontic treatment need assessed by the IOTN DHC was $20.9 \%$ at 12 years of age and $12.7 \%$ at 15 years. Manzanera et al. obtained very similar results (21.8\% and $17.1 \%$ respectively) in a representative sample from the same region (3). In France, Souames et al. found $21 \%$ in a sample of children aged 9 to 12 years
(14). In Iran, Hedayati et al. obtained similar results $(18.4 \%)$ in a sample aged between 11 and 14 years, as did Puertes-Fernández et al. in a sample of 12-year-old children in the Western Sahara $(18.1 \%)(15,16)$.

The IOTN AC assessed by the children gave treatment needs of $5.5 \%$ at 12 years and $1.1 \%$ at 15 years. Similar results have been found in other studies such as Manzanera et al., Souames et al., Hedayati et al., Josefsson et al., Nobile et al. and Hamdan, although Abdullah and Rock obtained a far higher percentage $(3,14,15,17-20)$. It should not be forgotten that although the IOTN AC is widely employed to ascertain the patients' own perceptions of their malocclusions, its validity has been questioned by some authors (21-23).

It was also found, as in other studies that the treatment need assessed by the patients (AC patient) was lower than that assessed by the examiner (AC examiner) $(24,25)$.

In relation to gender, no significant differences were found with any of the indices employed, which is in agreement with other authors (3).

The treatment need assessed by the DAI and the IOTN was slightly higher in the low social class than in the middle and high classes. While these differences were not significant, they nonetheless indicate a trend that has been displayed more strongly in other studies $(2,26)$.

The low diagnostic agreement between the different treatment need indices was borne out in the present 
study by the moderate kappa figure for agreement between DAI and modified IOTN, similar to that obtained by other authors $(27,28)$.

It may be stated that approximately $20 \%$ of the children needed orthodontic treatment and neither gender nor social class appeared to exert a significant influence on orthodontic treatment need.

\section{References}

1. Bellot-Arcís C, Montiel-Company JM, Almerich-Silla JM, Paredes-Gallardo V, Gandía-Franco JL. The use of occlusal indices in high-impact literature. Community Dent Health. 2012;29:45-8.

2. Baca-Garcia A, Bravo M, Baca P, Baca A, Junco P. Malocclusions and orthodontic treatment needs in a group of Spanish adolescents using the Dental Aesthetic Index. Int Dent J. 2004;54:138-42.

3. Manzanera D, Montiel-Company JM, Almerich-Silla JM, Gandía JL. Orthodontic treatment need in Spanish schoolchildren: an epidemiological study using the Index of Orthodontic Treatment Need. Eur J Orthod. 2009;31:180-3.

4. Alonso J, Pérez P, Sáez M, Murillo C. Validity of the occupation as an indicator of social class, according to the British Registrar General classification. Gac Sanit. 1997;11:205-13.

5. Hamamci N, Başaran G, Uysal E. Dental Aesthetic Index scores and perception of personal dental appearance among Turkish university students. Eur J Orthod. 2009;31:168-73.

6. Bernabé E, Flores-Mir C. Orthodontic treatment need in Peruvian young adults evaluated through dental aesthetic index. Angle Orthod. 2006;76:417-21.

7. Kerosuo H, Kerosuo E, Niemi M, Simola H. The need for treatment and satisfaction with dental appearance among young Finnish adults with and without a history of orthodontic treatment. J Orofac Orthop. 2000;61:330-40.

8. Onyeaso CO, Arowojolu MO, Taiwo JO. Periodontal status of orthodontic patients and the relationship between dental aesthetic index and community periodontal index of treatment need. Am J Orthod Dentofacial Orthop. 2003;124:714-20.

9. Bellot-Arcís C, Montiel-Company JM, Manzanera-Pastor D, Almerich-Silla JM. Orthodontic treatment need in a Spanish young adult population. Med Oral Patol Oral Cir Bucal. 2012;17:e638-43.

10. Manzanera D, Montiel-Company JM, Almerich-Silla JM, Gandía JL. Diagnostic agreement in the assessment of orthodontic treatment need using the Dental Aesthetic Index and the Index of Orthodontic Treatment Need. Eur J Orthod. 2010;32:193-8.

11. Jenny J, Cons N C, Kohout FJ, Jakobsen J. Differences in need for orthodontic treatment between native Americans and the general population based on DAI scores. J Public Health Dent. 1991;51:234-8.

12. Estioko LJ, Wright FAC, Morgan MV. Orthodontic treatment need of secondary schoolchildren in Heidelberg, Victoria: an epidemiologic study using the Dental Aesthetic Index. Community Dent Health. 1994;11:147-51.

13. Esa R, Razak LA, Allister JH. Epidemiology of malocclusion and orthodontic treatment need of 12-13-year-old Malaysian schoolchildren. Community Dent Health. 2001;18:31-6.

14. Souames M, Bassigny F, Zenati N, Roirdan PJ, Boy-Lefevre ML. Orthodontic treatment need in French schoolchildren: an epidemiological study using the Index of Orthodontic Treatment Need. Eur J Orthod. 2006;28:605-9.

15. Hedayati Z, Fattahi HR, Jahromi SB. The use of index of orthodontic treatment need in an Iranian population. J Indian Soc Pedod Prev Dent. 2007;25:10-4.

16. Puertes-Fernández N, Montiel-Company JM, Almerich-Silla JM, Manzanera D. Orthodontic treatment need in a 12-year-old population in the Western Sahara. Eur J Orthod. 2011;33:377-80.

17. Josefsson E, Bjerklin K, Lindsten R. Malocclusion frequency in Swedish and immigrant adolescents - influence of origin on orthodontic treatment need. Eur J Orthod. 2007;29:79-87.

18. Nobile CGA, Pavia M, Fortunato L, Angelillo IF. Prevalence and factors related to malocclusion and orthodontic treatment need in children and adolescents in Italy. Eur J Public Health. 2007;17:63741.

19. Hamdan AM. Orthodontic treatment need in Jordanian school children. Community Dent Health. 2001;18:177-80.

20. Abdullah MS, Rock WP. Assessment of orthodontic treatment need in 5112 Malaysian children using the IOTN and DAI indices. Community Dent Health. 2001;18:242-8.

21. de Oliveira CM, Sheiham A. Orthodontic treatment and its impact on oral health-related quality of life in Brazilian adolescents. J Orthod. 2004;31:20-7.

22. Flores-Mir C, Major PW, Salazar FR. Self-perceived orthodontic treatment need evaluated through 3 scales in a university population. J Orthod. 2004;31:329-34.

23. Bernabé E, Tsakos G, Messias de Oliveira C, Sheiham A. Impacts on daily performances attributed to malocclusions using the condition-specific feature of the Oral Impacts on Daily Performances Index. Angle Orthod. 2008;78:241-7.

24. Soh J, Sandham A. Orthodontic treatment need in Asian adult males. Angle Orthod. 2004;74:769-73.

25. Montiel-Company JM, Bellot-Arcís C, Almerich-Silla JM. Validation of the Psychosocial Impact of Dental Aesthetics Questionnaire (PIDAQ) in Spanish adolescents. Med Oral Patol Oral Cir Bucal. 2013;18:e168-713.

26. Tickle M, Kay EJ, Bearn D. Socio-economic status and orthodontic treatment need. Community Dent Oral Epidemiol. 1999;27:413-8.

27. Johnson M, Harkness M, Crowther P, Herbison P. A comparison of two methods of assessing orthodontic treatment need in the mixed dentition: DAI and IOTN. Aust Orthod J. 2000;16:82-7.

28. Hlongwa P, Beane RA, Seedat AK, Owen CP. Orthodontic treatment needs: comparison of two indices. SADJ. 2004;59:421-4. 